\title{
Anna Gondek*
}

\section{RACJONALNOŚĆ KRAKOWSKICH BEZDOMNYCH}

\begin{abstract}
Tekst poddaje analizie zjawisko bezdomności, głównie w odniesieniu do bezdomnych z terenów Krakowa, gdzie skala tego problemu jest szeroka. Przyjęta perspektywa badawcza odwołuje się do założeń teorii racjonalnego wyboru. Artykuł prezentuje część wniosków płynących z badań jakościowych wśród osób bezdomnych, przeprowadzonych w okresie od marca do kwietnia 2011 roku na potrzeby pracy licencjackiej. Przedstawione aspekty racjonalności odnoszą się do wyboru Krakowa jako „miejsca zamieszkania”, decyzji związanej z preferowanym miejscem noclegu, przystosowaniem do życia w bezdomności oraz przyjmowaniem postawy roszczeniowej, charakterystycznej dla osób bezdomnych.
\end{abstract}

Słowa kluczowe: bezdomność, bezdomni w Krakowie, teorie racjonalnego wyboru

Latem na krakowskich Plantach trudno znaleźć pustą ławkę. Nic w tym dziwnego - piękna pogoda i zieleń sprzyjają spacerom i spędzaniu czasu na świeżym powietrzu. Nierzadko jednak wszystkie miejsca odpoczynku są zajęte nie przez rodziny z dziećmi i miłośników natury, ale przez osoby bezdomne. Ławki stanowią dla nich miejsce spotkań, rozmów i rozmyślań, a nocą służą za łóżko i schronienie.

Na jednej z takich ławek siedział Siwy ${ }^{1}$. Na krakowskich Plantach spotkałam go w towarzystwie dwóch znajomych. Skończył dwa fakultety: filologię polską i socjologię. Internowany w czasach PRL-u, ma bardzo emocjonalny stosunek do polityki. Jest bezdomnym od 18 lat, bo ,rzucił tym wszystkim w diabły”:

Miałem dość oszustwa, dość kłamstwa i ja powiedziałem sobie, że ja muszę poznać ludzi ulicy. Nie ma większego miasta w Polsce, w którym bym nie był (B6P).

Jednym z miast, które Siwy kocha bardziej „niż niejedną kobietę kochał w życiu” (B6P), jest Kraków.

Artykuł poddaje analizie zjawiska bezdomności z perspektywy teorii racjonalnego wyboru. Przedstawię w nim część wniosków płynących z analizy wyników badań przeprowadzonych przeze mnie w okresie od marca do kwietnia 2011 roku na potrzeby pracy licencjackiej. Ich celem było sprawdzenie, czy w życiu bezdomnych obecna jest racjonalność, a jeżeli tak,

* AGH Akademia Górniczo-Hutnicza; a.budzowska@gmail.com

1 Rozmówca sam kazał tak siebie nazywać. Drugą jego ksywą jest „ojciec” bądź „tata” - określenia te wynikają z wieku badanego. 
to w jakich aspektach się ona przejawia. Analiza zjawiska pod tym względem miała służyć konstrukcji pewnych zaleceń i rekomendacji w zakresie wspierania osób bezdomnych.

Celem artykułu jest spojrzenie na zjawisko racjonalności osób bezdomnych w jego lokalnym wymiarze, dlatego badania przeprowadzane były na terenie Krakowa. Chociaż dobór próby na terenie tego miasta miał charakter głównie dogodnościowy, to jednak decyzja o wyborze tego właśnie miejsca może być traktowana jako jeden z wymiarów racjonalności. Część respondentów nie pochodziła z Krakowa, decyzję o „przeprowadzce” podjęła już będąc bezdomnymi. Kraków jest dla bezdomnych swoistym ,rajem” ze względu na bardzo rozbudowany system pomocy socjalnej. „Duża liczba furt zakonnych, które oferują pomoc, noclegownie, no i zamożni turyści. Bezdomni w ciągu dnia potrafią wyżebrać tyle, ile nie zarabia normalnie pracujący człowiek"”.

Na początku artykułu przedstawię krótko główne założenia teorii racjonalnego wyboru oraz określę zakres, w jakim zamierzam odnieść ją do analizy zjawiska bezdomności. Odwołując się do literatury przedmiotu, spróbuję wskazać obszary, w których racjonalność możliwa jest do zaobserwowania. Główną częścią mojego artykułu będzie jednak prezentacja wyników badań własnych, odnoszących się do lokalnego wymiaru zjawiska. W podsumowaniu artykułu znajdą się wnioski oraz pewne wskazówki dotyczące planowania pomocy dla osób bezdomnych.

\section{BEZDOMNOŚĆ Z PERSPEKTYWY TEORII RACJONALNEGO WYBORU}

Zadaniem teorii racjonalnego wyboru jest wyjaśnianie i przewidywanie działań społecznych, zarówno indywidualnych, jak i zbiorowych. Podstawowym założeniem jest racjonalność aktorów, którzy mając określone preferencje, podejmują działania zmierzające do maksymalizacji korzyści (użyteczności) lub minimalizacji kosztów. Aktorzy wybierają spośród możliwych opcji taki sposób postępowania, który - wedle ich wiedzy - doprowadzi do celu najmniejszym nakładem kosztów (Jasińska-Kania 2006: 135).

Teorie racjonalnego wyboru mają wśród socjologów wielu przeciwników. Krytycy kwestionują przede wszystkim założenie o racjonalności jednostek, twierdząc, że ludzie bardzo często kierują się emocjami, nawykami czy przesądami. Uważają, że wyjaśnianie makrostrukturalnych zmian w kategoriach racjonalnego wyboru jest zbyt upraszczające (Jasińska-Kania 2006: 137).

Mimo niewątpliwych ograniczeń, teorie racjonalnego wyboru mogą pomóc w thumaczeniu wielu ludzkich zachowań. Można odnieść je również do zjawiska bezdomności, chociaż potrzebne są pewne założenia oraz sprecyzowanie pojęcia racjonalności, które w tym wypadku jest stosowane. Odwołując się do kognitywnej teorii działania ${ }^{3}$, traktuję racjonalność

\footnotetext{
2 Wypowiedź Krzysztofa Galasa, twórcy filmu Kraków - miasto GIGANT.

3 Zgodnie z jej założeniami nawet fałszywe przekonania mogą być racjonalne, jeżeli bierze się pod uwagę racje postrzegane przez danego aktora jako silne, ponieważ celem racjonalności poznawczej ,nie jest maksymalizacja użyteczności, ale wiarygodność” (Boudon 2010: 229). Wybory dokonywane przez jednostkę muszą więc być przede wszystkim spójne z wyznawanym przez nią światopoglądem oraz hierarchią wartości.
} 
W sposób szerszy, jako postępowanie aktorów zgodnie ze swoimi mocnymi racjami. Moim zdaniem, w przypadku bezdomnych polega ono często raczej na minimalizacji kosztów niż na maksymalizacji zysków. Opiera się na założeniu, że lepiej bez żadnego wysiłku mieć cokolwiek niż angażować się w osiagnięcie czegoś więcej.

Eugeniusz Moczuk w swoim artykule Bezdomność jako problem spoleczny w świadomości osób bezdomnych (Moczuk 2000: 14) wprowadza podział na bezdomnych z przymusu, bezdomnych tymczasowych oraz bezdomnych z wyboru. Również inne typologie zwracają uwagę na istnienie kategorii osób, które na życie bez miejsca zamieszkania zdecydowały się świadomie ${ }^{4}$. Jak zresztą zauważa Aleksander Pindral (2010: 38), jest to podział powszechnie funkcjonujący w polskiej literaturze. O ile w przypadku bezdomności z konieczności wina za obecny stan przypisywana jest czynnikom egzogennym, sytuacjom losowym, o tyle w wypadku bezdomności z wyboru przyczyn upatruje się w samej jednostce, a jej stan uznaje się za „wybrany, determinowany uwarunkowaniami osobowościowymi” (tamże).

Współcześnie typologie tego rodzaju są coraz częściej krytykowane. Leszek Stankiewicz twierdzi, iż w opracowaniach zagranicznych nie pojawia się typ bezdomności, która w polskiej literaturze określana jest jako bezdomność z wyboru (Stankiewicz 2002: 67). Monika Oliwa-Ciesielska stwierdza dosłownie, iż:

(...) pogląd o istnieniu dobrowolnej bezdomności jest niesłuszny. Możliwy jest on jednak, gdyż istnieje wśród badaczy błędna tendencja do skupiania się na bieżących zachowaniach, przekonaniach, aktualnych postawach bezdomnych (...). Taki pogląd jest efektem niewnikania w społeczne, ekonomiczne i socjalizacyjne uwarunkowania bezdomności (...). W przypadku bezdomnych trwanie w tułaczym stylu życia sugerować może wprawdzie „wybór” bezdomności, jest to jednak zwykła reakcja obronna wobec poczucia braku realnych szans wyjścia z tego stanu bądź też reakcja spowodowana problemami natury psychicznej (Oliwa-Ciesielska 2004: 23).

Podobne zdanie ma Ewa Jagodzińska, prezes Stowarzyszenia Pomocy Bezdomnym:

Nie wierzę w bezdomność z wyboru. Zwykle mamy do czynienia z jakimiś konkretnymi przyczynami. Potem następuje przyzwyczajenie i zwycięża siła inercji (Jagodzińska za: Filas 1998: 39).

Na stronie Pomorskiego Forum na rzecz Wychodzenia z Bezdomności możemy znaleźć informację:

Badacze i praktycy zagadnienia bezdomności są przekonani, że bezdomność z rzeczywistego wyboru nie istnieje. U podłoża bezdomności zawsze pojawiają się inne problemy: np. uzależnienie, problemy psychiczne, rozpad rodziny itp. Deklaracja wyboru bezdomności jest raczej próbą usprawiedliwienia bezdomności niż realnym czynnikiem i przyczyną bezdomności (http://www. pfwb.org.pl/o_bezdomnosci/).

4 Zob. typologia M. Porowskiego w artykule Bezdomność - obraz zjawiska i populacji ludzi bezdomnych, w: Pedagogika społeczna, red. Tadeusz Pilch, Irena Lepalczyk, Warszawa 2005; typologia M. Pisarskiej w artykule Bezdomni w Łodzi. Analiza socjologiczna, „Polityka Społeczna”, nr 11/12, s. 8-11. 
Analizując sytuację osób niemających własnego miejsca zamieszkania, nie można zapomnieć o jednym ważnym problemie: domu nie można traktować jako jednorodnego dobra. Tak naprawdę rodzaj budynku mieszkalnego wiąże się z szeregiem różnego rodzaju opcji. Lepszy standard niesie ze sobą wyższą cenę, a im więcej pieniędzy przeznaczonych jest na mieszkanie, tym mniej zostaje ich na inne wydatki. Tak więc właściwie wybór nie polega na wskazaniu najlepszego z możliwych standardów mieszkaniowych, ale sprowadza się do decyzji dotyczącej najkorzystniejszej kombinacji dwóch elementów: odpowiedniego standardu mieszkaniowego i sumy pieniędzy pozostającej (po opłaceniu mieszkania) na inne cele. Każdy wybiera kombinację najkorzystniejszą dla siebie. Przy takim założeniu osobami bezdomnymi zostają ci, dla których bezdomność jest opcją atrakcyjniejszą niż opcja przewidująca posiadanie/wynajem mieszkania jakiegokolwiek standardu (O'Flaherty 1998: 99). Wybór bezdomności jest więc dokonywany w ekstremalnych warunkach ${ }^{5}$, ale trudno zaprzeczyć temu, iż może to być wybór racjonalny. Tym bardziej, że bezdomność niekoniecznie traktowana jest zawsze jako najgorszy z możliwych problemów, co doskonale ukazuje wypowiedź jednego z bezdomnych:

Narkotyki to był większy problem niż bezdomność. Nie widziałem bezdomności lub więzienia jako prawdziwego problemu. To jest tak, jakby sprawy mogły potoczyć się znacznie gorzej (Rice i in. 2007: 14).

Monika Oliwa-Ciesielska upatruje przyczyny stworzenia kategorii bezdomnych z wyboru w tendencji badaczy do skupiania się na aktualnych zachowaniach osób niemających miejsca zamieszkania (Oliwa-Ciesielska 2004: 23). Sugerować to może, iż wnioski o racjonalności osób bezdomnych można sformułować już na podstawie ich obecnego życia, abstrahując od samych przyczyn bezdomności. Jest to jednak prawdopodobnie racjonalność nieco odmienna od tej „tradycyjnej”, polegającej na maksymalizacji zysków.

Jak wygląda dzień człowieka bezdomnego? Przede wszystkim cechuje go specyficzna organizacja czasu. „Bezdomny żyje według wzoru bez pracy. Niebezdomny organizuje swoje życie wokół niej” (Piekut-Brodzka 2006: 237). Wcale nie oznacza to jednak, że bezdomny jest bezczynny. Przede wszystkim zmuszony jest do ciagłego poszukiwania miejsca na nocleg (Nóżka 2008: 218). Właśnie w tym działaniu przejawia się racjonalność osób bezdomnych. Rozpatrując różne opcje, kalkulują oni możliwe zyski i straty, chcąc dokonać najlepszego wyboru. Pozornie atrakcyjnym rozwiązaniem wydają się różnego typu schroniska i noclegownie ${ }^{6}$. „W tych miejscach nie można jednak przebywać pod wpływem alkoholu ani go spożywać. Dlatego nie wszyscy chcą lub mogą korzystać z miejsc noclegowych oferowanych w tych ośrodkach" (Nóżka 2008: 218). Trzeźwość można więc potraktować jako pewnego rodzaju koszt, który dla wielu bezdomnych wydaje się za wysoki. Tym bardziej, że ,pozostawanie kloszardem i życie bez pomocy instytucji daje wielu bezdomnym pewne profity. Pozwala na uniknięcie trudnej konfrontacji z regulaminowymi wymaganiami placówek pomocy" (Oliwa-Ciesielska 2004: 95).

5 W tym wypadku są to warunki związane niskimi przychodami.

6 Placówki dla osób bezdomnych różnią się sposobami funkcjonowania. Podział na różnego typu placówki można zobaczyć np. na stronie: http://www.bezdomnosc.edu.pl/images/PLIKI/Inne/opis\%20standardow\%20pomorskich.pdf 
Racjonalność krakowskich bezdomnych

Wybór miejsca noclegowego w dużym stopniu jest uzależniony od pory roku. Na wiosnę i w lecie:

(...) bezdomni najczęściej nocują w ogrodach działkowych, budują sobie szałasy lub zajmują opuszczone altanki albo ławki w miejskich parkach. (...) Zupełnie inaczej jest późną jesienią i w zimie, gdy spada temperatura. Wtedy bezdomni najczęściej poszukują miejsca w noclegowniach, u znajomych i w ciepłych klatkach schodowych (Głód 2008: 152).

Korzyści płynące z przebywania w czasie zimy w noclegowni są na tyle duże, że bezdomny decyduje się ponieść koszty trzeźwości.

Istotnym przejawem racjonalności jest pozyskiwanie środków finansowych - często poprzez żebranie ${ }^{7}$. Bezdomni znają różne sposoby wymuszania na jałmużniku jak największych korzyści. Umieją rozpoznać, jakie emocje wzbudzają w potencjalnym pomagającym odruch współczucia. Popularnymi sposobami jest opowiadanie o swoim życiu tak, aby wzruszyć słuchacza, lub też natarczywe błaganie wraz z ,przybieraniem specjalnych figur póz jak np. klękanie, składanie rąk, przecieranie chusteczką oczu itd." (Oliwa-Ciesielska 2004: 91). Jedna z bezdomnych tak wypowiedziała się na ten temat: „Staram się ubierać tak, żeby wzbudzać litość, bo to na ludzi najlepiej działa" (Oliwa-Ciesielska 2004: 91-92). Żebrać można na różne sposoby, między innymi „na wędkę” (zbierając na ulicy), „na klamkę” (chodząc po mieszkaniach) oraz „uprawiając turystkę” (prosić o pieniądze osoby wyglądające na turystów).

Poza żebraniem innym popularnym sposobem zarobkowania wśród bezdomnych jest zbieranie złomu i makulatury. Ich sytuacja jest o tyle trudna, że takich zbieraczy jest coraz więcej (Głód 2008: 67). „Zdarza się, że niektóre śmietniki znajdują się w rewirze jednej osoby lub grupy, co oznacza, że osoby te chronią dostępu do kontenerów, rezerwując dla siebie wszystko, co się w nich znajduje" (Nóżka 2008: 221).

Stephan Gillat podkreśla, że ,wielu spośród ludzi biednych umie gospodarować swoją biedą. Są zaradni i używają swoich pieniędzy oraz czasu w sposób niezwykle pragmatyczny" (Gillat 2001 za: Lister 2007: 164). Zdaniem Leszka Stankiewicza:

Bezdomny bardzo szybko uczy się sposobów na wygodne funkcjonowanie w alternatywnym świecie. Wie, gdzie może zimą liczyć na schronienie, gdzie dostanie odzież, a gdzie posiłek. Jego życie staje się wędrówką w poszukiwaniu dóbr, jakie oferują mu organizacje pomocowe. Uzależnia się od nich prawie tak mocno jak od alkoholu. Resztki swej aktywności i operatywności przeznacza na dowiadywanie się, gdzie coś dają, a następnie docieranie tam. Uważa, że skoro nie ma niczego, należy mu się wszystko. Bardziej aktywny bezdomny może dziennie odwiedzić kilka punktów i skorzystać z oferowanej pomocy w każdym z nich (Stankiewicz 2002: 97).

Przystosowanie bezdomnych do ich aktualnych warunków egzystencji i wejście w „kulturę bezdomności" sprawiają, że nieco inaczej zaczynają oni postrzegać świat, przysługujące im prawa i obowiązki. W konsekwencji bezdomni przyjmują charakterystyczną postawę roszczeniową. Bezdomni „często domagają się świadczeń socjalnych lub pieniędzy, uważając,

7 Nie chcę w tym miejscu utożsamiać zjawiska bezdomności ze zjawiskiem żebractwa. Wiele osób bezdomnych pozyskuje środki finansowe w inny sposób, np. pracując - niejednokrotnie na czarno. Objętość artykułu nie pozwala jednak na przedstawienie wszystkich sposobów zarobkowania osób bezdomnych. Skupiono się na żebractwie, jako że jest to jeden z popularniejszych sposobów zdobywania pieniędzy. 
że ze względu na ich aktualny stan należy im się to bezwarunkowo" (Stankiewicz 2002: 97). Takie podejście często wynika z przekonania o własnym ubóstwie i jednocześnie lepszej pozycji wszystkich innych osób. Bezdomni czują się ,uprawnieni do żądania wyrównywania własnych deficytów" (Oliwa-Ciesielska 2004: 58). Oczekują pomocy od rządu i samorządów, od dobrych ludzi, instytucji charytatywnych czy rodziny (Głód 2008: 192). Z czasem uzależniają się od pomocy, mając rozległą wiedzę na temat tego, co się im - osobom w sytuacji kryzysowej - należy ${ }^{8}$.

\section{RACJONALNOŚĆ KRAKOWSKICH BEZDOMNYCH W ŚWIETLE BADAŃ}

Do badań nad bezdomnymi można zastosować różne podejście. Zjawisko to można analizować zarówno z perspektywy ilościowej, jak i jakościowej. Wybór metod powinien być jednak podporządkowany problematyce badania. Spośród ogółu dostępnych należy wybrać te, które mogą najlepiej udzielić informacji na interesujące nas pytania (Nowak 2007: 47-48).

Do badań bezdomnych bardzo rzadko używa się metod jakościowych9. Można nawet stwierdzić, że dużo chętniej traktuje się ich jako jednostki analizy statystycznej niż jako osoby mające własne biografie, wartości, plany i marzenia.

W badaniach chciałam podejść do problemu bezdomności indywidualnie. Interesujące były dla mnie motywacje, wybory, sposób widzenia świata konkretnych osób. Chciałam sprawdzić, czy w swoim życiu kierują się one racjonalnością, a jeżeli tak, to w jaki sposób się ona przejawia.

W okresie od 10 marca do 7 kwietnia 2011 przeprowadziłam dwadzieścia jeden wywiadów, rozmawiając z dwudziestoma czteroma osobami bezdomnymi ${ }^{10}$. Celowo zastosowałam warstwowy dobór próby, polegający na tworzeniu podgrup w obrębie grupy dla celów

8 „Kulturę bezdomności” rozumiem podobnie jak pojęcie „kultura ubogich”, wprowadzone przez Oscara Lewisa w książce Sanchez i jego dzieci (Lewis 1964). Chodzi mi tutaj o pewien wzorzec życiowy, sposób postępowania, kodeks etyczny. Zazwyczaj dotyczy on tych bezdomnych, którzy określani są jako „kloszardzi” czy „kanałowi” (Poławski 2001: 5). Doszli oni już do ostatniego etapu wchodzenia w stan bezdomności i cechuje ich tzw. bezdomność właściwa (utrwalona), która ,charakteryzuje się pełnym przystosowaniem do warunków życiowych" (Stankiewicz 2005: 91).

9 Przewage perspektywy ilościowej w badaniach nad bezdomnymi można zauważyć chociażby w takich publikacjach jak: Dębski, Maciej i Sylwiusz Retkowski (red.). 2008. Psychospołeczny profil osób bezdomnych w Trójmieście, Gdańsk: Uniwersytet Gdański; Pisarska, Małgorzata. 1993. Bezdomni w Lodzi. Analiza socjologiczna. „Polityka Społeczna”, nr 11/12, s. 8-11. Wywiady przeprowadzane z bezdomnymi mają raczej charakter kwestionariuszowy niż pogłębiony: np. Oliwa-Ciesielska, Monika. 2004. Piętno nieprzypisania. Studium o wyizolowaniu społecznym bezdomnych, Poznań: Wydawnictwo Naukowe Uniwersytetu im. Adama Mickiewicza w Poznaniu (190 wywiadów kwestionariuszowych i zaledwie 12 narracyjnych).

10 Jeden z wywiadów miał formę, ,grupową" (czterech respondentów). Jego charakter wynikał z trudnych warunków panujących na terenie noclegowni, a dokładnie z braku odpowiedniego miejsca do przeprowadzenia badań. Konieczność zastosowania takiej metody przyniosła jednak zaskakująco pozytywne rezultaty - rozmówcy czuli się w większym gronie swobodniej i byli bardziej skłonni do dłuższych wypowiedzi. Wywiady przeprowadzane były odpowiednio na terenie Noclegowni i Schroniska dla Bezdomnych Mężczyzn przy ulicy Makuszyńskiego 19 w Krakowie, na terenie Schroniska dla Bezdomnych Kobiet przy ulicy Malborskiej w Krakowie oraz na krakowskich Plantach i w Galerii Krakowskiej. 
Racjonalność krakowskich bezdomnych

porównawczych. Selekcja wykorzystywała dwa kryteria: płeć i fakt zamieszkiwania na terenie noclegowni bądź schroniska. Za kryterium doboru uznałam również minimum roczny okres pozostawania w stanie bezdomności.

Wybór metodologii badań, polegającej na zastosowaniu wywiadu swobodnego z elementami wywiadu narracyjnego, wynikał z dwóch głównych powodów. Po pierwsze specyfika środowiska osób bezdomnych była dla mnie jako badacza obca, dlatego nie chciałam narzucać respondentom ściśle określonego kwestionariusza. Po drugie badania grup marginalizowanych niosą ze sobą szczególne problemy etyczne. Życie w długotrwałym ubóstwie, patologizacja, przebywanie w różnego rodzaju schroniskach i przytułkach - to wszystko sprawia, że osoby wykluczone znajdują się niejako w sytuacji nieustannej niewoli. Kostas Gounis (1996: 113) porównuje tę sytuację do Panoptikonu i stwierdza, że badania etnografa mogą stać się tylko dodatkowym ,okiem” podpatrującym działania członków grup marginalizowanych oraz przyczyniać się niejednokrotnie do pewnego rodzaju oswajania marginalizacji (Gounis 1996: 114). Zdaniem autora etyczne relacje możliwe są tylko w przypadku spotkania twarzą w twarz z osobą bezdomną i w żadnym razie nie mogą być mierzone przez efektywność podejmowanych rozwiązań. Skuteczność polityki społecznej odnosi się bowiem zawsze dopiero do stanu przyszłego. Etyka natomiast zostaje wyczerpana już w momencie spotkania (Gounis 1996: 115).

\subsection{KRAKÓW - MIASTO BEZDOMNYCH?}

W ciagu roku w Krakowie przebywa około 2200 osób bezdomnych. Miejski Ośrodek Pomocy Społecznej w Krakowie na swojej stronie internetowej informuje, że otrzymują oni wsparcie w postaci schronienia, ciepłych posiłków, świadczeń pieniężnych oraz pomocy rzeczowej. Są również aktywizowani zawodowo i społecznie, mogą uczestniczyć w grupach wsparcia, korzystać z pomocy specjalistów terapii uzależnień. W okresie zimowym liczba bezdomnych przebywających w Krakowie zwiększa się w związku z napływem osób bezdomnych z terenu całej Polski. Pracownicy socjalni podkreślają, że zdaniem bezdomnych rozbudowana sieć wsparcia organizacji pozarządowych i charytatywnych oraz niska stopa bezrobocia w Krakowie zwiększają szanse na zaspokojenie podstawowych potrzeb życiowych osób najuboższych ${ }^{11}$.

Jeden z rozmówców do Krakowa przyjechał na trzy dni, ale został na siedem miesięcy. Poznał kobietę i - jak sam podkreślił - „zakochał się i tyle” (B2P). Poza miłością kierowały nim również bardziej obiektywne powody pozostania w tym mieście. Duża liczba turystów umożliwiała mu zdobywanie niezbędnych środków finansowych:

Dzień to spędzam... nazywamy to pracą... no sępimy... Karton, napisane: NA PIWSKO, FOR BEER i się siedzi na kubeczku... Angole, oni też lubią piwo. Powie się „for beer”, to już jest chętny. Szczególnie w weekendy - wychodzą z baru, pijani i nie patrzą. Dla nich jakieś drobne to jest dziesięć złotych na przykład (B2P).

Kraków na miejsce swojego „zamieszkania” wybrał sobie też wspominany we wstępie Siwy. Chociaż podróżuje po całej Polsce, to właśnie do tego miasta wraca najczęściej. Poza

11 Zob.: http://www.mops.krakow.pl/index.php?option=com_content\&task=view\&id=1434\&Itemid=149 [15.09.2012]. 
atmosferą przyciaga go do niego rozbudowana sieć placówek pomocy społecznej. Mimo iż Siwy nigdy nie korzysta z możliwości noclegu w schronisku, to docenia inne formy wsparcia:

Nigdy nie uwierzę w to, a tym bardziej w Krakowie, że bezdomny musi chodzić brudny, zaniedbany i tak dalej. (...) Tutaj bezdomni w Krakowie... Na Kościuszki jest łaźnia dla bezdomnych, dają ciuchy, można się okąpać, można się ogolić i tak dalej (B6P).

W mniejszych miejscowościach zakres pomocy jest bardziej ograniczony. Jeden z respondentów przyjechał do Krakowa ze Skawiny, bo „tam nic nie ma, nie ma nic takiego” (B4P). Inny mężczyzna nie potrafił sprecyzować powodów swojej decyzji:

Ja jestem z Brzeska... a w Krakowie... Dlaczego? No bo jakoś, wie Pani, no, no... już się jakoś człowiek zadomowił, przyzwyczaił (B5P).

Wyjaśnienie może być też bardzo proste: „Przyjechałem raz i zakochałem się w tym mieście i nigdy w życiu stąd nie wyjadę" (B2P).

\subsection{GDZIE SPĘDZIĆ NOC?}

Podstawowym problemem, z którym musi zmagać się każda osoba bezdomna, jest znalezienie miejsca na nocleg. Zdarza się, że istnieje możliwość czasowego zamieszkania u rodziny, przyjaciół czy znajomych. Zazwyczaj jednak bezdomny zmuszony jest wybierać pomiędzy dwoma opcjami: schroniskiem i noclegiem na własną rękę - na dworcu, działkach czy w innych miejscach tego typu. W zależności od preferencji osoby bezdomne przyjmują jedną $\mathrm{z}$ trzech strategii: mieszkają w noclegowni na stałe, decydują się na nią tylko w porze zimowej lub całkowicie rezygnują z miejsca zamieszkania oferowanego im przez różnego typu instytucje.

Mieszkanie w noclegowni przynosi osobom bezdomnym wiele korzyści: dach nad głową, ciepłe schronienie, opiekę medyczna, możliwość korzystania z kuchni czy łazienki. Dlatego też niektórzy rozmówcy zdecydowali się na stałe zamieszkać na terenie placówki. Jeden z nich stwierdził: „Ja wolę tu siedzieć, bo mi to ratuje życie przynajmniej. Tu. Dlatego tu jestem" (B1S). Dla innego respondenta mieszkanie w noclegowni jest niejako oczywiste: „Przecież nie będę pod mostem mieszkać. Trzeba się wykąpać i jakoś wyglądać” (B3S).

Nocleg na terenie instytucji, poza oczywistymi korzyściami, niesie jednak ze sobą konieczność poniesienia pewnych kosztów. Głównym z nich jest nakaz przestrzegania regulaminu. Jak powiedział jeden z mieszkańców: „wie pani, rygor jest, godzina jest, to muszę być" (B7S). Dlatego też niektórzy bezdomni decydują się czasami na spędzenie kilku nocy poza przytułkiem: „Nikt nie słucha? (...) Idzie się na szczelinę, bo tu nie można wypić tak? Proste" (B7S). Inny mężczyzna opowiedział, co zrobić, aby w takiej sytuacji miejsce w placówce nie „przepadło”:

Jedną noc to można zadzwonić z terenu: „Nie ma mnie w Krakowie, proszę wpisać rezerwację” i nie ma żadnego problemu. Ja nie biorę tak, żebym przepadł, tylko zawszę mówię. Nie będzie mnie dwa tygodnie, jestem na działce (...). Tylko, że to, jak mówię, jest działka, to jest nieogrzewana, nie ma pieca, więc w zimie tam się nie da mieszkać (B4S). 
Od warunków atmosferycznych uzależniają swój nocleg również inni rozmówcy: „(...) to są już ostatnie moje dni... Przyjdzie już w kwietniu, tak, że w kwietniu opuszczam noclegownię (...) I wracam na zimę! Ha!” (B6S). To, że strategia tego typu jest popularna, potwierdzić może dodatkowo wypowiedź jednego z respondentów:

Jakby pani tutaj przyjechała na miesiąc czasu jak tu będzie ciepło, to nie będzie nawet połowy ludzi, nawet połowy. Przyjdą dopiero w listopadzie. A działki będą pełne - zapewniam panią. Wszystko się przenosi po wszystkich działkach w okolicy Krakowa (B3S).

Niektórzy bezdomni, opisywani w literaturze jako „pozaschroniskowi”, nigdy nie korzystają z noclegu oferowanego im przez różnego typu instytucje. Mieszkają na dworcu, na działkach czy „gdzie się da” (B5K). „Bo tam wymagania. Jak nie jestem trzeźwy, to drzwi zamykają i do widzenia. Nie ma litości” (B5P). Kobieta, która przed przybyciem do schroniska długo mieszkała na dworcu, stwierdziła:

No ale jak jest schronisko, to nie ma alkoholu, jak to się mówi, i dlatego dużo osób jest na dworcu, bo pije (...) tam jest swoboda - swawola i swoboda, jak to się mówi. Wszystko wolno, nikt nikomu nic nie zabrania (B5K).

Dla Siwego „hotel pod gwiazdami” to najlepsza opcja i innej możliwości nawet nie bierze pod uwagę (B6P).

\section{3. ,KOLEGA JEST TU WIĘCEJ BEZDOMNYM NIŻ JA - TO SIĘ NA TYM WSZYSTKIM ZNA"12}

Pozostawanie w bezdomności to sytuacja bardzo trudna. Wymaga przyjęcia pewnego rodzaju strategii umożliwiającej przetrwanie w specyficznych warunkach. Bezdomni, z którymi rozmawiałam, wykształcili różne sposoby radzenia sobie w codziennym życiu. Myślę, że mogą być przykładem, iż mimo swojego położenia, osoby te postępują zgodnie z zasadami racjonalności.

Zdaniem jednego respondentów umiejętność radzenia sobie w trudnej sytuacji jest nabyta, można powiedzieć, że wiąże się z wejściem w „kulturę bezdomności”. Gdyby nie pomoc kolegi, obeznanego w jadłodajniach i schroniskach, „nigdy by sobie nie poradził” (B3S). Tym bardziej, że wiedza przedstawicieli „utrwalonej”"13 bezdomności, dotycząca systemu pomocy socjalnej, bywa imponująca:

To wcześniej należało do PCK, a teraz do PKPS-u... To jest zależne też od prezydenta. (...) Za PCK to jak byłem małopolski to mnie nie przyjęli, no a teraz już tak ${ }^{14}$ (B6S).

Na terenie Krakowa istnieją różne punkty oferujące bezdomnym posiłki. Respondenci byli doskonale zorientowani, w których miejscach znajdują się jadłodajnie i w jakich godzinach są czynne. Niektórzy mają stałe miejsca, które odwiedzają: „tu, na Reformackiej,

12 Z wypowiedzi B4P dotyczącej „przystosowania się” do życia w bezdomności.

13 Bezdomność utrwalona/głęboka/chroniczna - patrz np. Pindral 2010: 44.

14 Chodzi tutaj o warunek ostatniego meldunku na terenie Krakowa. 
jestem przeważnie” (B5P), „idę na Skawińską” (B1P), „Krakowiaków” (B2S). Inni wybierają jadłodajnie w zależności od miejsca, w którym akurat się znajdują: „Tam gdzie się było. To na Dietla, to przy dworcu" (B5K).

Wielu bezdomnych narzekało na wysokość otrzymywanych zasiłków lub też deklarowało, iż nie korzysta wcale z pomocy społecznej. W takiej sytuacji respondenci musieli znaleźć inne sposoby na zdobycie potrzebnych im pieniędzy.

Do najpopularniejszych należało zbieranie puszek i żebranie. Jedna z pensjonariuszek schroniska, która przez rok mieszkała na dworcu, tak o tym opowiadała:

Rano pobudka i pierwsze co, to trzeba było załatwić jakieś pieniądze, żeby te, żeby był ten alkohol. To albo na żebranie, albo na puszki, albo na złom albo ten... coś tam chłopacy kombinowali, żeby miało się za co napić (B5K).

Z kolei mieszkaniec noclegowni thumaczył:

(...) bo na miedzi jest więcej. Ale na puszkach nie ma pani, bo (...) jak ja tu oddaję, to mam 3,70 - kilo puszek (...). Ale chcący te puszki znaleźć to nie wszędzie. Bo ja, jak na przykład chodzę, to jadę na Ruczaj (...). No i tam zawsze na tej budowie se zbieram puszek” (B1S).

Styl mówienia, który mógłby sugerować udzielania mi rad przez badanych, był bardzo częsty. Sprawiało to wrażenie, jakby respondenci chcieli mi pomóc wejść do „ich świata”, pokazać, jak sobie radzić w trudnej sytuacji: „Może pani iść nawet do dziesięciu jadłodajni, jak pani chce” (B1S), „Jak pani wybierze życie jako bezdomny, to na piciu pani długo nie pociagnie" (B6P).

\section{4. „SĄ ZUPKI JAKIEŚ PO KRAKOWIE... ALE TAM SIĘ NIE DA WEJŚŚ’”15}

Podczas przeprowadzania wywiadów z bezdomnymi chciałam uzyskać informacje, jak pomoc dla bezdomnych oceniają same osoby zainteresowane. Próbowałam w ten sposób zweryfikować hipotezę o występowaniu w tej grupie społecznej bardzo silnie roszczeniowej postawy. Przeprowadzone przeze mnie badania potwierdziły to często opisywane w literaturze zjawisko. Większość rozmówców bardzo krytycznie wypowiadała się na temat wsparcia, które oferują im różnego rodzaju organizacje. Niektórzy stwierdzali nawet, że ,nie ma żadnej pomocy" (B3S) lub w ogóle nie chcieli wypowiadać się na ten temat (B7S).

Respondenci, pytani o źródło dochodów, wymieniali zazwyczaj różne zasiłki, jednocześnie podkreślając, że są one stanowczo za niskie. Jeden z bezdomnych oburzył się, gdy po jego wypowiedzi na temat braku jakiejkolwiek pomocy, zapytałam o zasiłki, o których wcześniej wspominał: „No, ale co to Pani, co to Pani, co, co Pani kupi za dwieście złotych?” (B3S). Podobnego zdania był inny rozmówca: „Dwieście pięćdziesiąt złotych. Dwieście pięćdziesiąt? Ha ha...” (B3P). Bezdomny, który otrzymywał wyższy zasiłek, również nie był zadowolony: „(...) to jest czterysta czterdzieści na miesiąc - ale co to jest? Same papierosy kosztują" (B7S).

15 Z wypowiedzi B3S dotyczącej pomocy dla osób bezdomnych. 
Racjonalność krakowskich bezdomnych

Jeden z mieszkańców tak skomentował warunki mieszkaniowe w noclegowni:

A bo tu są tacy, którzy mówią, że tu dobrze mamy, bo jedzenie, to mamy gdzie spać. No gdzie? Tu że mamy telewizor, to że mamy tu spać. To mieszkanie jest do spania? Zero. Tu niektórzy coś, ale tak to zero, zero, zero. Nie ma nic kompletnie, nic kompletnie. Przychodzą siostry i dają leki - jak mają! A tak to musimy przynosić ze swojego (B12S).

Inny stwierdził: „Nie ma tu żadnych warunków. Ani socjalnych, ani do mieszkania, ani do niczego" (B3S).

Wiele osób bezdomnych, z którymi rozmawiałam, bardzo źle ocenia jakość i wielkość zapewnianych im posiłków.

Wie pani, bo te posiłki to... ja tam nie narzekam na te kobiety, bo ja tam, nie chce im robić tam „bydła”. (...) jak widzę, że mało, to mówię: weźcie se same to jedzcie” (B1S).

Niech pani patrzy, co oni tu dają. (...) A my to jeść musimy (B12S).

No zupy tylko i chleb - o! Tylko tyle, a tak to trzeba samemu kombinować, żeby kawałek kiełbasy dostać (...) (B7S).

Zdarzało się, że rozmówcy oceniali negatywnie nie tylko jakość pomocy, ale także sposób, w jaki ją otrzymywali. Jak stwierdził jeden z respondentów: „Rentę przynosi listonosz, a tutaj trzeba chodzić po pieniądze do MOPS-u” (B4S). Inny mieszkaniec noclegowni tłumaczył mi: „Trzeba iść i załatwić se. Bo tak to pani socjalna nie przyjdzie sama i nie będzie pytać, kto chce, a kto nie, tak? No po prostu trzeba samemu zadbać o to, żeby coś mieć"16 (B7S).

Postawa roszczeniowa często pojawiała się w wypowiedziach rozmówców, nie dotyczyła jednak wszystkich respondentów. Jeden z mieszkańców noclegowni uważa, że jedyną formą pomocy powinny być noclegownie oraz pomoc rzeczowa. Zdecydowanie sprzeciwia się on wszelkim zasiłkom, gdyż jak sam przyznał: ,wydają to na swoje potrzeby. Nawet na papierosy czy alkohol” (B6S). Pozytywnie pomoc dla bezdomnych oceniają też praktycznie wszystkie kobiety, z którymi rozmawiałam. Jedna z nich przyznaje, że ,jak na osobę, która nie pracuje, to jest duża pomoc" (B2K). Brak postawy roszczeniowej widoczny był także wśród części bezdomnych pozaschroniskowych.

\section{PODSUMOWANIE}

Krakowscy bezdomni muszą dokonywać w swoim życiu wielu wyborów, które często są racjonalne. Kalkulację zysków i strat można zaobserwować w takich aspektach ich życia jak np. odpowiednie przystosowanie się do warunków, w których zmuszeni są funkcjonować. Doskonała orientacja w lokalizacji różnych punktów pomocy, znajomość rozmaitych strategii żebrania czy innych sposobów zdobywania pieniędzy i papierosów - to przykłady pokazujące, że wielu bezdomnych umie doskonale gospodarować swoją biedą. Decyzje o wyborze

\footnotetext{
16 Warto zaznaczyć, że gabinet, w którym dyżurują panie z opieki socjalnej, znajduje się na terenie noclegowni.
} 
miejscu na nocleg również nie są rezultatem przypadku, ale wynikiem kalkulacji, w której bierze się pod uwagę własne preferencje (np. przedkładanie możliwości spożywania alkoholu) oraz warunki atmosferyczne.

Podejmując analizę bezdomności z uwzględnieniem teorii racjonalnego wyboru miałam pewne obawy o to, aby mój artykuł nie został niewłaściwie odczytany. Moim celem nie było udowodnienie, że bezdomność jest konsekwencją wyłącznie indywidualnych wyborów. Osoby nieposiadające miejsca zamieszkania to bardzo zróżnicowana grupa - niektórzy są mniej, inni bardziej odpowiedzialni za swoje położenie. W każdym jednak wypadku wsparcie w trudnej sytuacji jest niezbędne. Chodzi tylko o to, aby zarówno społeczeństwo, jak i twórcy programów pomocy nie postrzegali bezdomnego jako bezbronnej ofiary. Jak stwierdza Ruth Liester, istnieje w społeczeństwie tendencja do traktowania biednych w kategorii „,innych”, „redukując ich do biernych przedmiotów, przedstawiając ich albo w łagodnej postaci jako bezbronne ofiary, albo jako szkodliwe widmo leni, próżniaków" (Liester 2007: 153). Mam wrażenie, że podobnie sytuacja kształtuje się w przypadku funkcjonującego w społeczeństwie obrazu bezdomności.

W artykule chciałam pokazać, że brak miejsca zamieszkania nie redukuje osoby do bezbronnej ofiary. Bezdomni kierują się w swoim życiu racjonalnością, nawet jeżeli czasami zostaje ona wypaczona przez funkcjonowanie w kulturze biedy. Przeradza się ona wtedy często w postawę roszczeniową. Jest to światopogląd nieco nietypowy, jednak działania bezdomnych zgodne z takimi przekonaniami, można - w myśl kognitywnej teorii działania - uznać za racjonalne. Moim zdaniem, to właśnie tę specyficzną postać racjonalności - nastawioną przede wszystkim na minimalizację kosztów - powinniśmy zwalczać, jeżeli chcemy pomóc osobom bezdomnym. Darmowy posiłek i dach nad głową zapewnią być może doraźną pomoc, ale raczej nie przywrócą bezdomnych do funkcjonowania w społeczeństwie. Do tego potrzebna jest długofalowa pomoc. Dobrze byłoby, gdyby Kraków stał się „rajem” dla bezdomnych nie tylko dzięki dużej liczbie noclegowni i jadłodajni, ale też dzięki świadectwu osób, które z tej bezdomności wyszły właśnie w tym mieście.

\section{BIBLIOGRAFIA}

Boudon, Raymond. 2010. Wykraczajac poza teorię racjonalnego wyboru, w: Aleksander Manterys i Janusz Mucha (red.), Nowe perspektywy teorii socjologicznej. Wybór tekstów, Kraków: Zakład Wydawniczy NOMOS, s. 215-238.

Filas, Agnieszka. 1998. Upadek. Jak się zostaje bezdomnym, „Wprost”, nr 49, s. 39.

Głód, Franciszek. 2008. Bezdomni. Psychologiczno-pastoralna analiza życia, osobowości i próby resocjalizacji, Wrocław: Wrocławska Drukarnia Naukowa PAN.

Gounis, Kostas. 1996. Urban Marginality and Ethnographic Practice: on the Ethics of Fieldwork, „City \& Society”, nr 8, s. 108-118.

Jasińska-Kania, Aleksandra. 2006. Teoria racjonalnego wyboru. Wstęp, w: Aleksandra Jasińska-Kania, Lech M. Nijakowski, Jerzy Szacki i Marek Ziółkowski (red.), Współczesne teorie socjologiczne, Warszawa: Wydawnictwo Naukowe Scholar, s. 135-137.

Lister, Ruth. 2007. Bieda, Warszawa: Sic! 
Moczuk, Eugeniusz. 2000. Bezdomność jako problem społeczny w świadomości osób bezdomnych, „Polityka Społeczna”, nr 10, s. 14.

Nowak, Stefan. 2007. Metodologia badań społecznych, Warszawa: Wydawnictwo Naukowe PWN.

Nóżka, Marcjanna. 2008. Styl życia bezdomnego człowieka, w: Maciej Dębski i Krzysztof Stachura (red.), Oblicza bezdomności, Gdańsk: Wydawnictwo Uniwersytetu Gdańskiego, s. 214-227.

O’Flaherty, Brendan. 1998. Making Room. The Economics of Homelessness, Cambridge; Massachusetts; London: Harvard University Press.

Oliwa-Ciesielska, Monika. 2004. Piętno nieprzypisania. Studium o wyizolowaniu społecznym bezdomnych, Poznań: Wydawnictwo Naukowe Uniwersytetu im. Adama Mickiewicza w Poznaniu.

Piekut-Brodzka, Danuta. 2006. Bezdomność, Warszawa: Chrześcijańska Akademia Teologiczna.

Pindral, Aleksander. 2010. Definicje i typologie bezdomności, w: Maciej Dębski (red.), Problem bezdomności w Polsce. Wybrane aspekty, Gdańsk: Pomorskie Forum na rzecz Wychodzenia z Bezdomności, s. 31-51.

Poławski, Paweł. 2001. Obrazy bezdomnych i bezdomności. Instytucjonalizacja reakcji na problem społeczny, „Polityka Społeczna”, nr 1, s. 5.

Rice, Becky, Juliette Hough, Jackie Smith i Marc Francis. 2007. Reaching out, Londyn: Shelter.

Stankiewicz, Leszek. 2002. Zrozumieć bezdomność (aspekty polityki społecznej), Olsztyn: Wydawnictwo Uniwersytetu Warmińsko-Mazurskiego, dostęp online: http://www.pfwb. org.pl/o_bezdomnosci/ [17.01.2011].

Zawsze trzeba mieć nadzieję! Wywiad z Krzysztofem Galasem, dostęp online: http://www. niedziela.pl/artykul_w_niedzieli.php?doc=nd200815\&nr=33 [17.01.2011].

\section{BEZDOMNI SCHRONISKOWI MĘŻCZYŹNI:}

B1S - J.A., mężczyzna, wiek: 44 lata, bezdomny od 10 lat, wywiad przeprowadzony w dniu 10.03.2011 na terenie Noclegowni i Schroniska dla Bezdomnych Mężczyzn przy ulicy Makuszyńskiego 19 w Krakowie.

B2S - J.W., mężczyzna, wiek: 56 lat, bezdomny od 15 lat, wywiad przeprowadzony w dniu 10.03.2011 na terenie Noclegowni i Schroniska dla Bezdomnych Mężczyzn przy ulicy Makuszyńskiego 19 w Krakowie.

B3S - P.W., mężczyzna, wiek: 59 lat, bezdomny od 10 lat, wywiad przeprowadzony w dniu 10.03.2011 na terenie Noclegowni i Schroniska dla Bezdomnych Mężczyzn przy ulicy Makuszyńskiego 19 w Krakowie.

B4S - B.D., mężczyzna, wiek: 55 lat, bezdomny od 10 lat, wywiad przeprowadzony w dniu 10.03.2011 na terenie Noclegowni i Schroniska dla Bezdomnych Mężczyzn przy ulicy Makuszyńskiego 19 w Krakowie.

B5S - H.W., mężczyzna, wiek: 57 lat, bezdomny od 10 lat, wywiad przeprowadzony w dniu 14.03.2011 na terenie Noclegowni i Schroniska dla Bezdomnych Mężczyzn przy ulicy Makuszyńskiego 19 w Krakowie. 
B6S - M.O., mężczyzna, wiek: 35 lat, bezdomny od 17 lat, wywiad przeprowadzony w dniu 14.03.2011 na terenie Noclegowni i Schroniska dla Bezdomnych Mężczyzn przy ulicy Makuszyńskiego 19 w Krakowie.

B7S - W.C., mężczyzna, wiek: 54 lata, bezdomny od 10 lat, wywiad przeprowadzony w dniu 14.03.2011 na terenie Noclegowni i Schroniska dla Bezdomnych Mężczyzn przy ulicy Makuszyńskiego 19 w Krakowie.

B8S - J.K., mężczyzna, wiek: 65 lat, bezdomny od czterech lat, wywiad przeprowadzony w dniu 14.03.2011 na terenie Noclegowni i Schroniska dla Bezdomnych Mężczyzn przy ulicy Makuszyńskiego 19 w Krakowie.

B9S - A.K., mężczyzna, wiek: 49 lat, bezdomny od roku, wywiad przeprowadzony w dniu 14.03.2011 na terenie Noclegowni i Schroniska dla Bezdomnych Mężczyzn przy ulicy Makuszyńskiego 19 w Krakowie.

B10S - K.K., mężczyzna, wiek: 46 lat, bezdomny od ośmiu lat, wywiad przeprowadzony w dniu 14.03.2011 na terenie Noclegowni i Schroniska dla Bezdomnych Mężczyzn przy ulicy Makuszyńskiego 19 w Krakowie.

B11S - P.F., mężczyzna, wiek: 37 lat, bezdomny od pół roku, wywiad przeprowadzony w dniu 14.03.2011 na terenie Noclegowni i Schroniska dla Bezdomnych Mężczyzn przy ulicy Makuszyńskiego 19 w Krakowie.

B12S - W.B., mężczyzna, wiek: 58 lat, bezdomny od 11 lat, wywiad przeprowadzony w dniu 14.03.2011 na terenie Noclegowni i Schroniska dla Bezdomnych Mężczyzn przy ulicy Makuszyńskiego 19 w Krakowie.

B13S - R.T., mężczyzna, wiek: 46 lat, bezdomny od dwóch lat, wywiad przeprowadzony w dniu 10.03.2011 na terenie Noclegowni i Schroniska dla Bezdomnych Mężczyzn przy ulicy Makuszyńskiego 19 w Krakowie.

\section{BEZDOMNE SCHRONISKOWE KOBIETY:}

B1K - X.X. (nie podano inicjałów), kobieta, wiek: 49 lat, bezdomna od 2,5 roku, wywiad przeprowadzony w dniu 28.03.2011 na terenie Schroniska dla Bezdomnych Kobiet przy ulicy Malborskiej 64b w Krakowie.

B2K - Y.Y. (nie podano inicjałów), kobieta, wiek: 41 lat, bezdomna od czterech lat, wywiad przeprowadzony w dniu 28.03.2011 na terenie Schroniska dla Bezdomnych Kobiet przy ulicy Malborskiej w Krakowie.

B3K - Z.Z. (nie podano inicjałów), kobieta, wiek: 49 lat, bezdomna od półtora roku, wywiad przeprowadzony w dniu 28.03.2011 na terenie Schroniska dla Bezdomnych Kobiet przy ulicy Malborskiej w Krakowie.

B4K - X.Y. (nie podano inicjałów), kobieta, wiek: 56 lat, bezdomna od ośmiu miesięcy, wywiad przeprowadzony w dniu 28.03.2011 na terenie Schroniska dla Bezdomnych Kobiet przy ulicy Malborskiej w Krakowie.

B5K - Y.Z. (nie podano inicjałów), kobieta, wiek: 33 lata, bezdomna od dziesięciu lat, wywiad przeprowadzony w dniu 28.03.2011 na terenie Schroniska dla Bezdomnych Kobiet przy ulicy Malborskiej w Krakowie. 


\section{BEZDOMNI POZASCHRONISKOWI:}

B1P - Z.Z. (nie podano inicjałów), mężczyzna, wiek: około 50 lat (rozmówca nie podał wieku), bezdomny od 17 lat, wywiad przeprowadzony w dniu 6.04.2011 na terenie Galerii Krakowskiej.

B2P - Y.Y. (nie podano inicjałów), mężczyzna, wiek około 30 lat (rozmówca nie podał wieku), bezdomny od trzech lat, wywiad przeprowadzony w dniu 7.04.2011 na terenie krakowskich Plant.

B3P - M.S., mężczyzna, wiek: 42 lata, bezdomny od 21 lat, wywiad przeprowadzony w dniu 7.04.2011 na terenie krakowskich Plant.

B4P - X.X. (nie podano inicjałów), mężczyzna, wiek: 43 lata, bezdomny od roku, wywiad przeprowadzony w dniu 7.04.2011 na terenie krakowskich Plant.

B5P - M.O., mężczyzna, wiek: 57 lat, bezdomny od około 30 lat, wywiad przeprowadzony w dniu 7.04.2011 na terenie krakowskich Plant.

B6P -A.X. (nie podano nazwiska), mężczyzna, wiek: 64 lata, bezdomny od 18 lat, wywiad przeprowadzony w dniu 7.04.2011 na terenie krakowskich Plant.

\section{RATIONALITY OF THE HOMELESS IN KRAKOW}

The text is based on an analysis of the phenomenon of homelessness, especially in relation to large scale of this problem in Krakow. Accepted research perspective refers to the assumptions of rational choice theories. The article presents some conclusions drawn from qualitative research among homeless people, conducted from March to April 2011 for the thesis. Presented aspects of rationality refers to the choice of Krakow, as a 'place of residence', decisions related to the preferred type of accommodation, adaptation to life in the homelessness and demanding attitude characteristic for homeless people.

Key words: homelessness, the homeless in Krakow, theories of rational choice 